\title{
The Influence of Repeated Cold Exposure to VFAs Metabolism in Intact Sheep Liver Slices
}

\author{
Masanori Fujita, Atsuo Ushikoshi, Katsuo SeTo \\ and *Arthur L. BLACK \\ Department of Physiology, Kochi Medical School, Nankoku-shi 781-51 \\ *Department of Physiological Sciences, University of California, \\ Davis, California, U.S.A.
}

(Received February 4, 1980)

\begin{abstract}
In order to investigate the metabolic use of VFAs in cold-exposed sheep liver, fifteen Merino sheep were repeatedly exposed to an ambient temperature of $2^{\circ} \mathrm{C}$. On the $1 \mathrm{st}$, 4th and 7 th day of cold exposure, ${ }^{14} \mathrm{C}$ incorporation from ${ }^{14} \mathrm{C}$ acetate, propionate and butyrate into $\mathrm{CO}_{2}$, glucose, ketone bodies, cholesterol ester, triglyceride, free cholesterol, NEFA and phospholipid in the liver slices were observed. ${ }^{14} \mathrm{C}$ incorporation from ${ }^{14} \mathrm{C}$-acetate into $\mathrm{CO}_{2}$, glucose, ketone bodies tended to increase and into cholesterol ester, triglyceride, free cholesterol, NEFA tended to decrease on the 1st, 4th or 7th day of cold exposure, but, was changed to decrease into ketone bodies on the 4 th day. ${ }^{14} \mathrm{C}$ incorporation from ${ }^{14} \mathrm{C}$-propionate into $\mathrm{CO}_{2}$, glucose, triglyceride, NEFA, phospholipid tended to increase and into cholesterol ester, free cholesterol tended to decrease on the 1st or 4th day of cold exposure, but was changed to increase into free cholesterol on the ${ }^{4}$ th day. ${ }^{14} \mathrm{C}$ incorporation from ${ }^{14} \mathrm{C}$-butyrate into $\mathrm{CO}_{2}$, glucose, ketone bodies, triglyceride, free cholesterol, NEFA, phospholipid tended to increase and into cholesterol ester tended to decrease on the 1st, 4th or 7th day of clod exposure, but, was changed to increase into cholesterol ester on the 4th day. The results of this experiment indicated that VFAs could be used in various metabolic purpose on cold exposure in sheep liver slices. Further, it was also indicated that each VFA showed their own characteristic ways of metabolic use in such a case of this experiment.
\end{abstract}

$J p n . J$. Zootech. Sci., $51(8): 588-594,1980$

This study was designed to investigate the metabolic fate of volatile fatty acids in cold-exposed sheep liver in vitro. In the ruminant, much is still unknown about the orign of cold-induced thermogenesis which is the lack of entire energy demand on cold exposure. Recent results indicated that the utilization of $\mathrm{NEFA}^{3.4)}$, $\mathrm{VFAs}^{2 \text {, }}$, glu$\operatorname{cose}^{1.21)}$ and glycerol ${ }^{10)}$ increases in cold-exposed ruminant animals, also, these results suggested that the each contribution of these substrates could not be efficient to coldinduced thermogenesis individually. It can be considered that cold-induced thermogenesis should be a result of complex mixture of various metabolic accelerations on cold exposure ${ }^{8)}$. In this respect, VFAs, which is the major energy source in ruminant animals ${ }^{5.23)}$, is supposed to be the minor contribution to cold-induced thermogenesis ${ }^{15)}$, because of their food depending exogenous character ${ }^{7,18)}$, however, some intermetabolic character of each VFA should be looked once again. Cold accelerated metabolic increase must need a large quantity of some useful intermetabolites, therefore, we were very interested in the metabolic use of VFAs on cold exposed ruminant animals. 


\section{Materials and Methods}

Thirty Merino sheep, weighing about $45 \mathrm{~kg}$, were used. The animals were kept with a temperature of $20^{\circ} \mathrm{C}$ for more than 20 days. Subsequently, the animals were exposed to cold environment with a temperature of $2^{\circ} \mathrm{C}$ for 1,4 and 7 days from 12:00 to 24:00 repeatedly in every day. At the end of 1st, 4 th and 7 th day of cold exosure, the animals were slaughtered at 24:00 in every experiment, and fresh liver was obtained as $0.4 \mathrm{~mm}$ thick slices. During the experiment, $600 \mathrm{~g}$ of alfalfa hay and $400 \mathrm{~g}$ of commercial concentrate were given once a day at 8:00. Water was available ad libitum.

Analytical procedures were almost the same as previously reported ${ }^{23}$. That is, liver slices incubation was carried out in $50 \mathrm{ml}$ Erlenmyer flasks fitted with $2 \mathrm{ml}$ center well. Each flask containned $2 \mathrm{~g}$ of liver slices, $10 \mathrm{ml}$ of Krebs-Ringer bicarbonate buffer ( $\mathrm{pH} 7.4), 100 \mu$ moles $(1 \mu \mathrm{Ci})$ of ${ }^{14} \mathrm{C}$-labelled short-chain fatty acid. The flasks were closed with serum caps after gassing with $\mathrm{O}_{2}+\mathrm{CO}_{3}$ (95:5). Incubation (3 flasks for each animals: ${ }^{14} \mathrm{C}-$ glucose, ${ }^{14} \mathrm{C}-$ ketone bodies and $\mathrm{CO}_{2}$ assay were carried in different flasks) was carried out for $3 \mathrm{hr}$. at $38^{\circ} \mathrm{C}$ during the shaking at 100 strokes $/ \mathrm{min}$. The ${ }^{14} \mathrm{CO}_{2}$ assay was made after incubation by injecting $1 \mathrm{ml}$ of Hyamine into the center wells of the Erlenmyer flask $0.5 \mathrm{ml}$ of $10 \mathrm{~N} \mathrm{H}_{2} \mathrm{SO}_{4}$ into the medium. The flasks were shaken for $30 \mathrm{~min}$ in ice prior to quantitative removal of Hyamine for estimation of total radioactivity in the trapped $\mathrm{CO}_{2}$. The glucose was isolated from incubation medium by the method of JoNES ${ }^{13)}$. Ketone bodies fraction was analyzed by the method of May and $\mathrm{FELTS}^{20}$. Total lipids in the tissue and medium were extracted with a mixture of chloroform and metanol (2:1) by the method of Folch, Less and SLOaneSTANLY ${ }^{11}$. That is, separation of the lipid fraction was effected on sillicic acid columns. Successive fractions were eluted with $2 \%$ ethyl ether in $n$-hexane (fraction A: cholesterol ester), $10 \%$ ethyl ether in $\mathrm{n}$-hexane (fraction B: triglyceride), $50 \%$ ethyl ether in $\mathrm{n}$-hexane (fraction $\mathrm{C}$ : free cholesterol), $25 \%$ methanol in ethyl ether (fraction D: NEFA) and pure methanol (fraction E: phospholipid).

The ${ }^{14} \mathrm{C}$ activity in each of these fractions was measured by liquid scintillation spectrometer using $15 \mathrm{ml}$ of scintillation solution (toluene composed of $0.01 \%$ POPOP and $0.5 \% \mathrm{PPO}$ ). Total nitrogen in the liver slices was determined by the microKjeldahl method, and the results were expressed as mean $\mu \mathrm{mCi} / 3 \mathrm{hr}$. $/ \mathrm{g}$ of tissue nitrogen \pm S. D. (standard deviation). Each study involved 5 animals.

\section{Results}

1. Acetate metabolism

The representative result of ${ }^{14} \mathrm{C}$ incorporation from ${ }^{14} \mathrm{C}$-acetate into $\mathrm{CO}_{2}$, glucose, ketone bodies, cholesterol ester, triglyceride, free cholesterol, NEFA and phospholipid on the 1st, 4th and 7th day of cold exposure were shown in Table 1 with their control value respectively. 
Fujita, Ushikoshi, Seto and Black

Table 1. The infuence of repeated cold exposure to acetate metabolism in intact sheep liver slices.

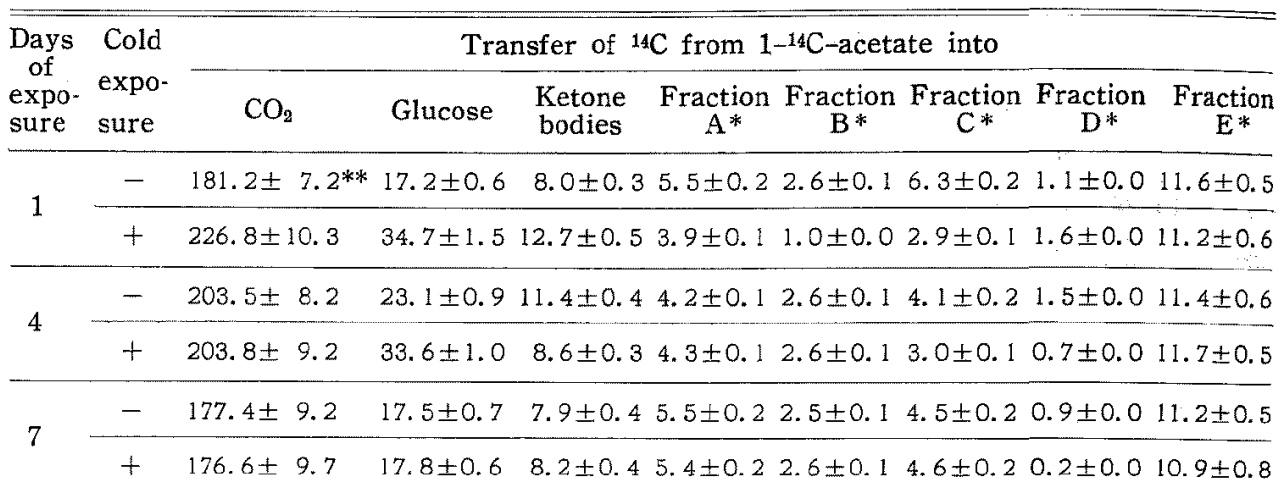

Slices $(2 \mathrm{~g})$ were incubated in Krebs-Ringer bicarbonate buffer with ${ }^{14} \mathrm{C}$-acetate $(100 \mu$ moles, $1 \mu \mathrm{Ci}$ ). * Fraction $\mathrm{A}, \mathrm{B}, \mathrm{C}, \mathrm{D}$ and $\mathrm{E}$ were composed of cholesterol ester, triglyceride, free cholesterol, NEFA and phospholipid respectively. **: Mean $\mu \mathrm{mCi}$ per $100 \mathrm{mg}$ of tissue $\mathrm{N} \pm$ $\mathrm{S}$. D. in 5 animals.

Almost the every change was observed on the 1st day of cold exposure. That is, on the 1st day of cold exposure, ${ }^{14} \mathrm{C}$ incorporation from ${ }^{14} \mathrm{C}$-acetate into $\mathrm{CO}_{2}$, glucose and ketone bodies increased, then ${ }^{14} \mathrm{C}$ incorporation into cholesterol ester, triglyceride, free cholesterol and NEFA decreased. On the 4 th day of cold exposure, ${ }^{14} \mathrm{C}$ incorporation into glucose still remained to increase, and ${ }^{14} \mathrm{C}$ incorporation into free cholesterol and NEFA also still remained to decrease. But the increase of ${ }^{14} \mathrm{C}$ incorporation into ketone bodies was changed to decrease, and the decrease of ${ }^{14} \mathrm{C}$ incorporation into cholesterol ester was ceased. On the 7 th day of cold exposure, ${ }^{14} \mathrm{C}$ incorporation into NEFA still more remained to decrease and the others were ceased. No other changes were observed so far.

Table 2. The influence of repeated cold exposure to propionate metabolism in intact sheep liver slices.

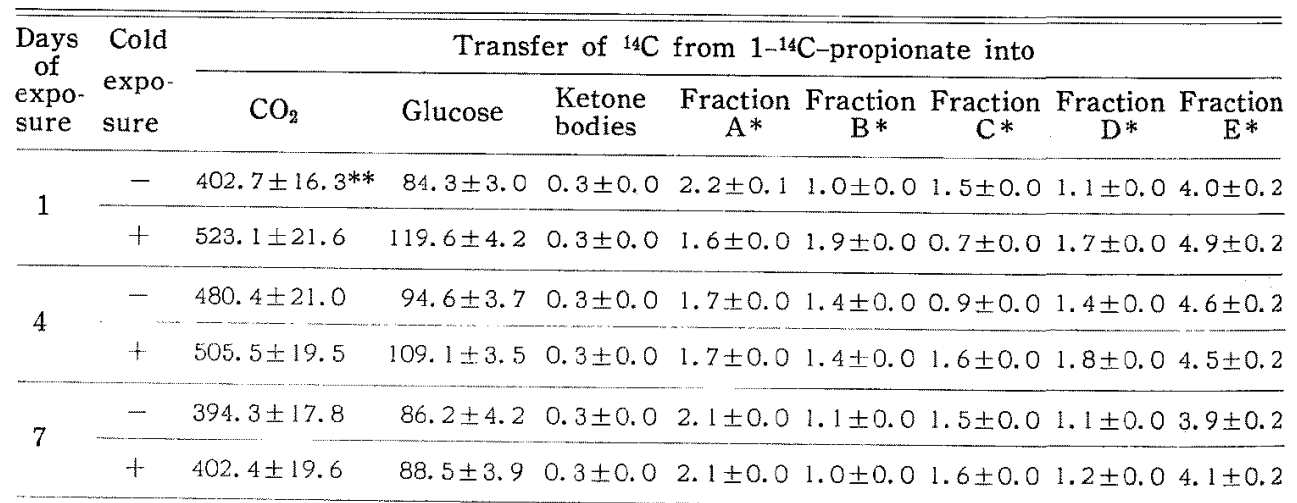

Slices $(2 \mathrm{~g})$ were incubated in Krebs-Ringer bicarbonate buffer with ${ }^{14} \mathrm{C}$-propionic acid $(100 \mu$ moles, $1 \mu \mathrm{C}$ i). * Fraction $\mathrm{A}, \mathrm{B}, \mathrm{C}, \mathrm{D}$ and $\mathrm{E}$ were composed of cholesterol ester, triglyceride, free cholesterol, NEFA and phospholipid respectively. **Mean $\mu \mathrm{mCi}$ per $100 \mathrm{mg}$ of tissue $\mathrm{N} \pm \mathrm{S}$. D. in 5 animals. 


\section{Propionate metabolism}

The representative result of ${ }^{14} \mathrm{C}$ incorporation from ${ }^{14} \mathrm{C}$-propionate into $\mathrm{CO}_{2}$, glucose, keton bodies, cholesterol ester, triglycerid, free cholesterol, NEFA and phospholipid on the 1st, 4th and 7th day of cold exposure are shown in Table 2 with their control value respectively.

Almost the every change was observed on the 1st day of cold exposure as was acetate. That is, on the 1 st day of cold exposure, ${ }^{14} \mathrm{C}$ incorporation from ${ }^{14} \mathrm{C}$-propionate into $\mathrm{CO}_{2}$, glucose, triglyceride, NEFA and phospholipid increased, then ${ }^{14} \mathrm{C}$ incorporation into cholesterol ester and free cholesterol decreased. On the 4th day of cold exposure, the decrease of ${ }^{14} \mathrm{C}$ incorporation into free cholesterol was changed to increase, and ${ }^{14} \mathrm{C}$ incorporation into NEFA still remainned to increase. The other changes were ceased so far.

3. butyrate metabolism

The representative result of ${ }^{14} \mathrm{C}$ incorporation from ${ }^{14} \mathrm{C}$-butyrate into $\mathrm{CO}_{2}$, glucose, ketone bodies, cholesterol ester, triglyceride, free cholesterol, NEFA and phospholipid on the 1st, 4 th and 7 th day of cold exposure are shown in Table 3 with their control value respectively.

Table 3. The influence of repeated cold exposure to butyrate metabolism in intact sheep liver slices.

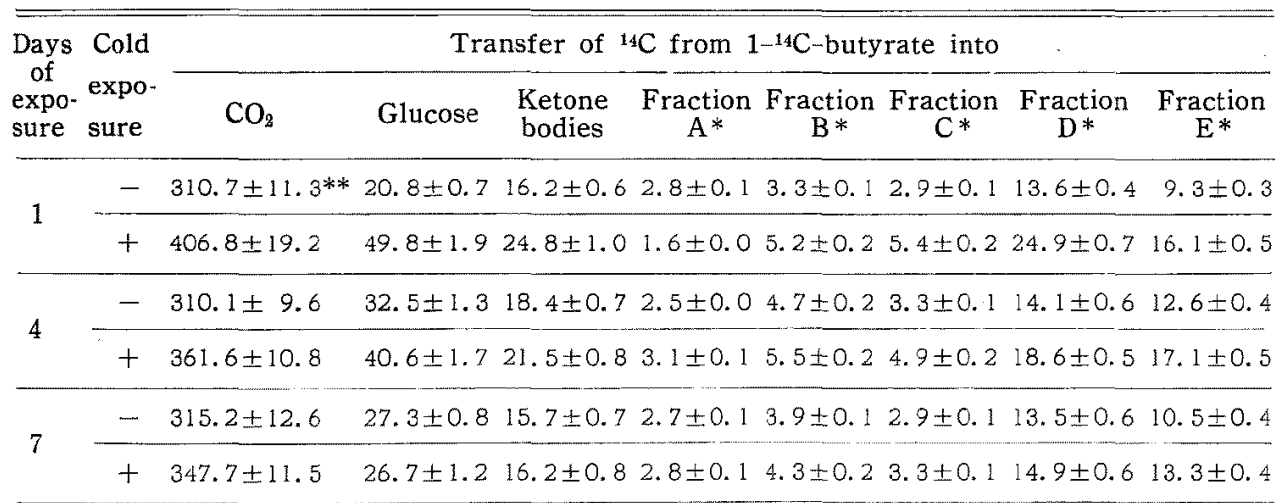

Slices $(2 \mathrm{~g})$ were incubated in Krebs-Ringer bicarbonate buffer with ${ }^{14} \mathrm{C}$-butyrate $(100 \mu$ moles, $1 \mu \mathrm{C}$ ). * Fraction $\mathrm{A}, \mathrm{B}, \mathrm{C}, \mathrm{D}$ and $\mathrm{E}$ were composed of cholesterol ester, triglyceride, free cholesterol, NEFA and phospohlipid respectively. **Mean $\mu \mathrm{mCi}$ per $100 \mathrm{mg}$ of tissue $\mathrm{N} \pm \mathrm{S}$. D. in 5 animals.

In contrast with acetate or propionate metabolism, there observed various changes on the each stage of cold exposure, or with substrates. On the 1st day of cold exposure, ${ }^{14} \mathrm{C}$ incorporation from ${ }^{14} \mathrm{C}$-butyrate into $\mathrm{CO}_{2}$, glucose, ketone bodies, triglyceride, free cholesterol, NEFA and phospholipid increased, then ${ }^{14} \mathrm{C}$ incorporation into cholesterol ester decreased. On the 4 th day of cold exposure, ${ }^{14} \mathrm{C}$ incorporation into $\mathrm{CO}_{2}$, glucose, triglyceride, free cholesterol, NEFA and phospholipid still remained to increase, then the increase of ${ }^{14} \mathrm{C}$ incorporation into ketone bodies was ceased. But, the 
decrease of ${ }^{14} \mathrm{C}$ incorporation into cholesterol ester reversed to increase. On the 7 th day of coad exposure, ${ }^{14} \mathrm{C}$ incorporation into $\mathrm{CO}_{2}$, triglyceride, free cholesterol and phospholipid still remained to increase. The other changes were all ceased so far.

\section{Discussion}

In this experiment, normal feeding intact sheep were exposed to cold repeatedly for 7 days. It should be considered that shivering thermogenesis would be dominant to non-shivering thermogenesis during the period of this 7 days of cold exposure ${ }^{8}$. But, it could be also considered that non-shivering thermogenesis plays some parts in cold-induced thermogenesis in this experiment ${ }^{12}$. Among some of the non-shivering thermogenic organs, liver is known to be one of the major heat productive organs, there, some significant changes were expected to be observed with VFAs metabolism in this experiment.

First, ${ }^{14} \mathrm{C}$ incorporation from ${ }^{14} \mathrm{C}$-VFAs into $\mathrm{CO}_{2}$ increased in some stage of this experiment. Taking VFAs for direct energy source to cold-induced thermogenesis, the results of this experiment suggested the possibility of contribution from VFAs to cold induced thermogenesis. But, it also suggested that this contribution from VFAs could not be sufficient for paying the lack of entire energy demand on cold exposure, because, the rate of increasing ${ }^{14} \mathrm{C}$ incorporation from ${ }^{14} \mathrm{C}$-VFAs into $\mathrm{CO}_{2}$ was much less than the rate of increasing whole body heat production as previously reported ${ }^{9}$. There also observed different pattern of ${ }^{14} \mathrm{C}$ incorporation between acetate, propionate and butyrate. ${ }^{14} \mathrm{C}$ incorporation from ${ }^{14} \mathrm{C}$-acetate and propionate into $\mathrm{CO}_{2}$ increased only on the 1st day of cold exposure, however, ${ }^{14} \mathrm{C}$ incorporation from ${ }^{14} \mathrm{C}$-butyrate increased through the 7 days of cold exposure. This might be a reflection of some different metabolic use of each VFA, but, details would be made obvious by another studies.

Secondly, Different catabolic patterns were observed with acetate and butyrate metabolism. ${ }^{14} \mathrm{C}$ incorporation from ${ }^{14} \mathrm{C}$-acetate and butyrate into ketone bodies in creased on the 1st day of cold exposure, but, it was changed to decrease on the 4th day of cold exposure with acetate. Owing to the great energy demand on cold exposure, the unbalanced energy expenditure by glucolysis and lipolysis produced so much of ketone bodies ${ }^{18}$. It was suggested that the formation of ketone bodies from acetate and butyrate would be accelerated by cold exposure.

Thirdly, in contrast with above mentioned oxidative catabolism, VFAs can be glucogenic precursor. ${ }^{14} \mathrm{C}$ incorporation from ${ }^{14} \mathrm{C}$-VFAs into glucose increased in some satge of this experiment. This result was borne out by previous report of increasing plasma glucose turnover rate in cold exposed sheep ${ }^{1,21}$. As for propionate, propionic acid is known to be one of the major glucogenic precursor in the ruminant ${ }^{6,17}$. But, it was indicated ${ }^{10)}$ that propionic acid could not so greatly contribute to cold induced glucose demand ${ }^{121)}$ which is almost equal to gluconeogenesis in the ruminant, because of the same reason as VFAs to cold induced thermogenesis. This point of view was confirmed with the result of this experiment. That is, the increase of ${ }^{14} \mathrm{C}$ incorporation into glucose from ${ }^{14} \mathrm{C}$-propionate was observed only on the 1 st day of cold 
exposure. On the other hand, acetate and butyrate have been known to be ketogenic substrates, and, these have been supposed not to be a substantial precursor to gluconeogenesis, even if the C-skeleton might be incorporated into glucose in the course of glucose synthesis. As a fact, considerable value of ${ }^{14} \mathrm{C}$ incorporation from ${ }^{14} \mathrm{C}$-acetate and butyrate was observed on the 1st and 4th day of cold exposure in this experiment. The result of this experiment suggested some possible role of acetate and butyrate in the emergent demand of gluconeogenesis.

Fourthly, it was indicated that lipogenesis was effected by cold exposure. ${ }^{14} \mathrm{C}$ incorporation from ${ }^{14} \mathrm{C}$-acetate into each of lipid fraction generally decreased without into phospholipid, but, ${ }^{14} \mathrm{C}$ incorporation from ${ }^{14} \mathrm{C}$-propionate and butyrate tended to increase without into cholesterol ester. This result, reflecting the intermetabolic significance of acetate, suggested that there would be more essential metabolic use of acetate than to be used for lipogenesis on cold exposure. Further, propionate and butyrate seemed to have a still more important lipogenic significance on cold exposure. It is well known that lipogenesis increases in cold-exposed animals as well as lipolysis ${ }^{19}$. One of the reason of this phenomenon should be due to increasing heat production and decreasing heat loss. With regard to this point of view, it could be said that acetate might be heat productive and propionate, butyrate might be heat protective. Data of this experiment suggested that this heat protective action of propionate and butyrate would be carried out by the form of NEFA or triglyceride. Cholesterol ester and phospholipid have been known to be used to form some hormones $^{(4)}$ or body structures. Owing to cold accelerated physiological reactions in various organs, the utilization of these substrates might be increased, however, details are still unknown.

Finally, the data of this experiment suggested some possible role of VFAs metabolism in cold exposed sheep. But, to make this problem more cleanly, so many studies are desirable to be performed in the near future.

\section{References}

1) Ambo, K., M. Fujta, M. Sugawara and T. Tsuda, Enyiron, Control in Biol., 14 (4): 115121. 1976

2) Bell, A. W., J. W. Gardner and G. E. Thompson, Br. J. Nutr., 32: 471-477. 1974.

3) Bert, A. W., P. L. Clarke and G. E. Thom son, Q. J. Exp. Physiol., 60: 267-284. 1975.

4) Bell, A.W.. and G. E. Thompson, Am. J. Physiol., 237 (4): E309-E315. 1979.

5) Bergman, E. N., R.S. Reyd, M. G. Murray, J. M. Brockway and F. G. Whitelaw, Biochem. J., 97: 53-58, 1965.

6) Bergman, E. N., E. R. Walter and K. Kon, Am. J. Physiol., 211 (3): 793-799. 1966.

7) Bensadoun, A., O. L. Paladines and J. T. Reid, J. Dairy Sci., 45: 1203-1210. 1962.

8) Davis, T. R. A., Federation Proc., 22: 777-782. 1963.

9) Fujita, M., M. Sugawara, K. Ambo and T. Tsuda, Environ. Control in Biol., 14 (4): 107114. 1976.

10) Fujrta, M., Proc. Japanese Society for Ani. Nutr. and Metabolism, $22(1)$ : 15-25. 1978.

11) Forch, J., M. Lees and G. H. Slonne-Stanley, J. Biol. Chem., 222: 497-509. 1957.

12) Heroux, O.E., J. Page, J. Leblanc, R. Ledue, A. Gilbert, A. Villematra and P. Rivest, J. Appl. Physiol., 38: 436-442. 1975.

13) Jones, G. B., Analytic. Biochem., 12: 249-258. 1965.

14) Kimura, F., S. Ishida, K. Seto and M. Kawakami, Endokrinologie, 67 (2): 172-183. 1976. 


\title{
Fujita, Ushikoshi, Seto and Black
}

15) Kennedy, P. M., R. J. Christopherson and L. P. Milligan, Br. J. Nutr., 36: 231-242. 1976.

16) Leng, R. A. and G. J. Leonard, Br. J. Nutr,, 19: 469-485. 1965.

17) Leng, R. A., J. W. Steel and J. R. Luick, Biochem. J., 103: 785-790. 1967.

18) Mayes, P.A. A., Metabolism, 11: 781-799. 1962.

19) Masoro, E. J., Physiol. Revs,, 46: 67-101. 1966.

20) Mayes, P.A. and J. M. Felts, Biochem. J., 102: 230-235, 1967.

21) Mскау, D.G., B.A. Young and L.P. Millgan, In Energy Metabolism of Farm Animals (Menke, K. H., H. J. Lantzsch and J.R. Reichl, eds.) 39-42. Hohenheim: Universität Hohenheim Dokumentationsstelle, 1974.

22) Seto, K., H. Negoro, M. Yoshyda, M. Mouki, M. Manaka, M. Kawakami and A. L. Black, J. Physiol. Soc. Japan, 34: 746-756, 1972.

23) Warner, A. C. I., Nutr. Abstr. Rev., 34: 339-346. 1964.

\section{めん羊の肝スライスにおりる低級脂肪酸代謝に 対する反復寒冷暴露の影響}

\author{
藤田正範・牛越犜夫・瀬戸勝男・A. L. Black.* \\ 高知医科大学第一生理学教室, 南国市 781-51 \\ *カリホルニヤ大学生理科学科, ディビス, \\ カリホル $=7$, U.S.A.
}

\footnotetext{
寒冷暴麗め九羊の熱生廒過程に占める低級脂肪酸代謝 の役割定検索する目的で，反復寒冷暴露め九羊の肝ス イスに㧍ける ${ }^{14} \mathrm{C}$ 標識低級脂肪酸よりの $\mathrm{CO}_{2}$, グルコー ス、ケトン体，コレステロールエステル，トリクリセり ド，遊離コレステロール，遊傩脂肪酸及びリン脂質への ${ }^{14} \mathrm{C}$ の取込み家観察した。. ${ }^{14} \mathrm{C}$-酶酸よりの $\mathrm{CO}_{2}$, グルニ ースタトン体への ${ }^{14} \mathrm{C}$ の取込多は暴露後 1,4 または 7 日目に増加し，コレステロールエステルトリグリセリ ド，遊離コレステロール，遊離脂肪酸への取远みは同様 に減少した。しかし，暴露 4 日目にケトン体への取込み の堌減が逆転した. ${ }^{14} \mathrm{C}$ プロピオン酸よりの $\mathrm{CO}_{2}$, グル コース,トリグリセリド，遊離脂肪酸，リン脂貿への
}

${ }^{14} \mathrm{C}$ の取込みは暴露後 1 または 4 日目に增加し、コレス テロールエステル, 遊離コレステロールヘの取达双法同 様に減少した。しかし，暴露 4 日目に遊離コレステロー ル人の取迅子の增隇は逆転した。. ${ }^{14} \mathrm{C}$-酪酸よりの $\mathrm{CO}_{2}$ r グルコース, ケトン体，トリダリセリ:ド，遊離コレステ ロール，遊離脂肪酸，リン脂質への ${ }^{14} \mathrm{C} の$ 取込み法暴露 後 1,4又は 7 日目に堌加し、コレステロールエステル人 の取込みは減少したしかし，暴露 4 日目にコレステロ 一ルェステルへの取込多の増減は逆転した。本実験の結 果は寒冷暴露めえ羊の肝における低級脂肪酸の代謝利用 の方向を明らかにした。

日畜会報，51(8)：588-594,1980 